\title{
TECHNOLOGICAL PEDAGOGICAL CONTENT KNOWLEDGE (TPACK) CRAFT: UTILIZATION OF THE TPACK WHEN DESIGNING THE GEOGEBRA ACTIVITIES
}

\author{
Rabia Gül KIRIKÇILAR, Avni YILDIZ
}

\begin{abstract}
There are many studies with a focus on examining and developing individuals' Technological Pedagogical Content Knowledge (TPACK). When examining these studies, one can recognize that these studies are usually conducted with preservice teachers. Nevertheless, examining teachers' preparation processes of classroom activities constitutes an important area for the improvement of instruction. In this respect, it is important to examine the preparatory process of computer assisted activities that mathematics teachers include in their lessons. Hence, in this study, middle school mathematics teachers' utilizations of the TPACK when designing classroom activities, which they prepared by using the GeoGebra software, were investigated. Participants of the study consisted of three mathematics teachers who have been working in a middle school. The data was collected by using an observation form, which was developed by the authors, and by conducting semi-structured interviews with the participants. The quantitative and qualitative data analysis methods were used in analyzing the collected data. The findings showed that teachers had difficulty integrating their pedagogical knowledge into the technology throughout the activity design processes and had deficiencies in terms of the TPACK.
\end{abstract}

Key words: middle school teachers, observation form, GeoGebra dynamic software, TPACK.

\section{Introduction}

It is important for teachers to show students how to use and reinforce the knowledge that they already have and produce new knowledge. By the transition from teacher-centered to student-centered teaching, a new period in education has begun in which learners take the role of constructer of the knowledge rather than being memorizer of the knowledge (Airasian \& Walsh 1997). Examining the literature one can notice that technology, which is one of the most important components of the 21 st century, has been shaping and structuring the knowledge of students. Hence, at the present time, education and technology have become two interdependent concepts (Komis, Ergazakia \& Zogzaa 2007; McCannon \& Crews 2000).

Today, integrating technology into education is seen as an important part of effective teaching programs (Pierson 2001). Therefore, teachers are expected to use the provided technologies in their classrooms as well as expected to integrate these technologies into learning environments (Gündüz \& Odabaş1 2004). In addition, the most important indicator of a relationship between technology and teaching is to do well planning about how technology would facilitate learning (Zhao, Pugh, Sheldon \& Byers 2002). As a matter of fact, in recent years studies have shown that besides technology

Receive 31 January 2018, accepted 16 April 2018.

Cite as: Kirikçilar, R. G. \& Yildiz, A. (2018). Technological pedagogical content knowledge (TPACK) craft: Utilization of the TPACK when designing the GeoGebra activities. Acta Didactica Napocensia, 11(1), 101-116. DOI: 10.24193/adn.11.1.8.

*This manuscript was part of the first author's master's thesis, which she prepared under the guidance of the second author, entitled by "The Usage of Technological Pedagogical Content Knowledge During The Process of Preparing Activities with Dynamic Software by Middle School Mathematics Teachers" 
knowledge teachers should have well-established content knowledge and pedagogical competencies that they can use in reflecting these content knowledge into technological environments (Anderson 2008).

Shulman (1986) found that teachers primarily focused on the content knowledge and foregrounded their field expertise, and they ignored pedagogical information. Consequently, Shulman (1987) integrated pedagogical knowledge into the content knowledge by adding it under the content knowledge category. Then, along with technological developments, the inclusion of technology alongside content and pedagogical knowledge has brought along other approaches (Mishra \& Koehler 2006). Mishra and Koehler (2006) divided TPACK into seven sub-knowledge categories: Technology Knowledge (TK), Pedagogical Knowledge (PK), Content Knowledge (CK), Technological Pedagogical Knowledge (TPK), Technological Content Knowledge (TCK), Pedagogical Content Knowledge (PCK), and Technological Pedagogical Content Knowledge (TPACK).

Mudzimiri (2012) stated that it is unrealistic to expect that teachers' TPACK will develop immediately since they can be influenced by many factors (technological experience, content knowledge, beliefs about technology). Akyüz (2016), on the other hand, stated that in order to determine teachers' TPACK levels, one should examine the lesson plans and activities they prepared and conclude accordingly. Hence, in this study, we investigated middle school mathematics teachers' usage of TPACK in the process of preparing dynamic software-assisted activities.

There are paid and free dynamic mathematics software (e.g., the GeoGebra, Dr. Geo, Euklides, Calques3D, Cindrella, Cabri, and Geometric Sketchpad) used in teaching process, structuring concepts, and facilitating students' mathematical thinking (Güven \& Karataş 2003). The validity and reliability of these software are provided by experts in various studies. These software usually deal with relationships among points, lines, polygons, circles, and other geometric concepts (Sangwin 2007). Considering their advantages, dynamic mathematics software is stated to be more influential on students' learning than other classroom tools (Baltac1 2014). Moreover, these software enable students' visualization of geometric relationships between objects by letting them clicking and dragging on objects (Arzarello, Olivero, Paola, \& Robutti 2002). The GeoGebra is the most known and frequently used dynamic software (Baltacı, Yıldız, \& Kösa 2015). The GeoGebra have an important place in education because it is user friendly, free, language options are available (Kutluca \& Zengin 2011) and combines features of both algebra and geometry (Hohenwarter \& Jones 2007).

When the studies on TPACK are examined, one can see that these studies usually focused on teachers' or preservice teachers' TPACK qualifications in classroom environments (Ceylan, Türk, Yaman, \& Kabakç1-Yurdakul 2014; Kabakç1-Yurdakul 2011; Tuncer \& Bahadır 2016) and on the development of a scale for TPACK (Graham et al. 2009; Kabakç1-Yurdakul et al. 2012; Schmidt et al. 2009). In addition, there are studies on teachers' or preservice teachers' TPACK development, self-efficacy, and perceptions on the TPACK (Karataş, Pişkin-Tunç, Demiray, \& Yılmaz 2016; Yiğit, Alev, Yurt, \& Mazlum 2017). On the other hand, there are also studies on the TPACK components and the relationship between these components in the literature (Guzey \& Roehrig 2009; Jang \& Chen 2010; Morsink et al. 2011; Niess, Van-Zee, \& Gillow-Wiles 2011). However, few studies (e.g., KuşkayaMumcu, Haşlaman \& Koçak-Usluel 2008; Pamuk 2012) have been focused on the integration of technology into TPACK.

The studies on the GeoGebra software are generally aimed at investigating students', teachers', or preservice teachers' opinions on this software, and the effects of the software on students, teachers, preservice teachers, and learning environments (Baltac1, Yıldız \& Kösa 2015; Baltacı \& Baki 2017; Er \& Sağlam-Kaya 2017; Kutluca \& Zengin 2011). In addition, there are studies on the dimensions of the GeoGebra software such as the usage of it and design of interactive applications (Rincon 2009). However, it is necessary to elaborate on mathematics teachers' TPACK in detail during their classroom activities design processes using GeoGebra.

The research problem of this study was determined as "How do secondary school mathematics teachers use their TPACK when preparing GeoGebra dynamic software-assisted activities that they intend to implement in classrooms?" In this respect, the purpose of this study was to develop a valid, reliable, and useful observation form to determine teachers' utilizations of TPACK and to determine 
behaviors that they exhibit when preparing their activities using the GeoGebra dynamic software. The observation form, which has passed through certain processes, believed to help individuals who want to conduct research in this context. Therefore, we consider that the observation form can be used in different topics and contexts.

\section{Method}

In this section, we presented information about the model and design of the study, participants, data collection tools, and data collection and analysis procedures.

\section{1. The Model of the Study}

The examination of mathematics teachers' utilizations of TPACK when preparing course activities using dynamic mathematics software requires long time of research. In this respect, we decided to work with very few participants to avoid some possible problems and to get an in-depth idea about the process of teachers' utilizations of TPACK. Therefore, this study designed as a case study in which quantitative and qualitative research methods used together in analyzing the collected data.

\section{2. The Design of the Study}

The study consists of three phases: Preparation, pilot, and actual application. In the preparation phase, drafts of the observation form and interview questions were prepared by reading the relevant literature. While creating a pool of teacher behaviors, which were included in the observation form, we were guided by seven sub-dimensions of TPACK provided by Mishra and Koehler (2006). In addition, we followed the studies (e.g., Archambault \& Crippen 2009; Kabakçı Yurdakul et al. 2012; Schmidt et al. 2009) conducted on the TPACK during the formation of the observation form. Thus, the information in the literature is gathered together and expressed as the behaviors teachers can exhibit during the activity design processes. Next, both the observation form and interview questions were developed by referring to the expert opinions.

Before proceeding with the actual data collection, we decided conducting a pilot of the study to test the validity and reliability of the observation form and to gain experience about the data collection process. As a result of the pilot study, we detected some deficiencies in the observation form and correct these deficiencies. In addition, we included the teacher behaviors that were not in the form but were observed during the pilot study. The observation form was given the final form after correcting items based on the expert opinions. The final form was tested based on content validity, and as a result validity and reliability of the form were obtained.

Semi-structured interviews were conducted with teachers before the actual implementation of study. We decided to conduct interviews to have general knowledge about the teachers, to receive their trust, and to be able to choose a purposeful sample. In our second meeting with the teachers, we asked them to prepare activities using the GeoGebra software. Our purpose with this step was to determine the levels of teachers' utilization of technology. To determine these levels, we used three levels determined by Hughes (2005) and adopted by Demir (2011). Based on Table 1, teachers were divided into levels according to their technology usage levels, and one mathematics teacher was selected from each level for the study. Then, in the next meeting, we asked the selected teachers to prepare activities with the GeoGebra. The reason for asking middle school teachers to prepare activities using the GeoGebra was to detect their utilizations of the TPACK and to observe their behaviors using the observation form. 
Table 1. The levels of teachers' utilizations of technology (Demir 2011)

\begin{tabular}{|l|l|}
\hline Level 0 & $\begin{array}{l}\text { These are situations where technology is not used during the teaching process. It is } \\
\text { just like using computers for playing games. }\end{array}$ \\
\hline Level 1 & $\begin{array}{l}\text { This technology level refers to using one type of file and reflecting it on the board } \\
\text { during the teaching process. }\end{array}$ \\
\hline Level 2 & $\begin{array}{l}\text { In this level, the technology for carrying out the teaching process quickly and } \\
\text { efficiently. For instance, instead of drawing the parabola on a board, describing it } \\
\text { using technological applications can be given as an example for this level. }\end{array}$ \\
\hline Level 3 & $\begin{array}{l}\text { In this level, dynamic software, which guide learners in their learning of a subject, } \\
\text { are used for studying a subject in-depth. For example, according to this level, one } \\
\text { can show the slope of a curve that is drawn at a given point to a function is equal to } \\
\text { the derivative of this function at that point. }\end{array}$ \\
\hline
\end{tabular}

\section{3. Participants}

Three middle school mathematics teachers participated in the study. Teachers were chosen based on their willingness to work, level of technology use, and knowledge on the GeoGebra dynamic software. The teachers were given codes: Teacher 1's was a female teacher with 3 years professional experience, and her level of utilization of technology was determined as Level 2. Teacher 2 was a male teacher with 6 years professional experience, and he was determined as a Level 1 teacher. Teacher 3 was a male teacher with 4 years professional experience, and his level was determined as Level 3. The teachers' ages ranged between 26 and 33 .

\section{4. The Data Collection}

Under this heading, we explain the data collection tools and data collection process.

\section{4. 1. The Data Collection Tools}

In this study, the data were collected using the observation form and conducting semi-structured interviews with the participants. Semi-structured interviews were conducted before and during the application process of the study. The reason for conducting interviews before the application process is to know the teachers better and to have knowledge about their familiarity with the technology. Whereas, the purpose of conducting interviews during the application process was to better explain the events observed during the preparation process of the activities, which the teachers are supposed to use during the course, and to better understand their behaviors that they exhibited during the preparation process. According to the literature, it may be necessary to obtain additional information from the participants on the subject of a study and to discuss the parts that were not understood. In this regard, the interviews were conducted during the observation process in order to better explain the behaviors teachers exhibited for their utilizations of the TPACK. In these interviews, we asked questions to the teachers that were similar to the following ones: "Do students have conceptual misconceptions about this topic?" and "Why did you scan the triangular region?

Considering the purpose of the study, it was necessary to have a good pool of behaviors, which were obtained from the related literature. For example, the behavior "Being able to benefit from the technology-supported communication environments (blog, forum, chat, e-mail, etc.) in the teaching process" (Kabakçı Yurdakul et al. 2012) was added to the observation form as "The teacher benefitted from the technology supported communication environments (Google, GeoGebraTube, forum, etc.) during the activity design process." Another example was that the behavior "In my class, I can plan the sequence of concepts (from general to specific and simple to complex)" (Archambault \& Crippen 2009) was added to the form as "The teacher planned the sequence of concepts (from general to specific and simple to complex) in the activity design process." 
After the above processes, a draft of the observation form was prepared. This observation form was used during the pilot study. The pilot study was carried out in 2015-2016 academic year. Two teachers who were teaching mathematics in a middle school participated in the pilot study in which we conducted more than one interview with each teacher. In the pilot study, five activities were observed for each teacher, and so a total of 10 activities were examined. As a result of the pilot study, some deficiencies were found in the observation form. Hence, we decided to make some changes in the observation form considering the opinions received from field experts. Moreover, the teachers exhibited some behaviors that were not shown on the observation form, so we also included these behaviors in the form. These behaviors were as follows: "Designed activities by considering how many lesson hours required for completing learning outcomes of a topic," "The teacher appropriately transferred the subject matter that he/she will be teaching into the GeoGebra software," and "The teacher was able to make abstraction by making meaning from his/her mathematical concrete experiences."

After making the changes mentioned above in the observation form, authors controlled the content validity of the form. Lawshe technique was used when determining the content validity of the observation form items. Lawshe technique consisted of six stages: Forming the field expert group, preparing the candidate observation forms, obtaining expert opinions, obtaining the content validity rates for each item, obtaining content validity indices for the form, and giving the final shape of the form according to the content validity indices (McGartland et al. 2003). We asked experts to rate each form item as "necessary," "correction needed,", or "unnecessary," and left a section at the end of the form for the behaviors that they wanted to add.

\section{4. 2. The Data Collection Procedure}

During the observation process, the author occasionally took notes on the exhibited teacher behaviors and asked questions in order to get more detailed information on these behaviors. By conducting such interviews during the observation process, we ensured that the data collection tools supported each other and variations between these two tolls have been made. After observing the activities related to the relevant learning outcomes, observation forms were using the notes taken during the process. Thus, in each activity preparation process, we marked the appropriate places in the observation forms to determine which of the behaviors on the form were exhibited. Because the purpose was to determine how many times each behavior was exhibited, one single marking was made for each behavior exhibited in an activity.

\section{5. Analysis of the Data}

The data obtained in the study were analyzed using the qualitative and quantitative data analysis methods. Interviews with the teachers were transcribed verbatim, and teachers' responses to questions during the activity preparation process were analyzed. Next, we tried to match the teachers' responses with the appropriate codes on the observation form. Then, we determined the total number of times each behavior was exhibited in the observation form and tabulated these numbers for each observation process and presented in the findings. A code was for each behavior in the observation form (Table 2), which was developed by the authors, and in the findings section, comments were made on given texts using these codes. 
Table 2. The codes given in the observation form for behaviors exhibited by teachers in order to investigate their utilizations of TPACK

\begin{tabular}{|c|c|}
\hline Behaviors & Code \\
\hline $\begin{array}{l}\text { The teacher accordingly updated the requirements (environment, time, etc.) for the } \\
\text { subject taught. }\end{array}$ & A1 \\
\hline $\begin{array}{l}\text { The teacher benefitted from the technology supported communication } \\
\text { environments (Google, GeoGebraTube, forum, etc.) during the activity design } \\
\text { process. }\end{array}$ & A2 \\
\hline The teacher was able to keep up-to-date his/her technological knowledge. & A3 \\
\hline $\begin{array}{l}\text { The teacher engaged in interdisciplinary work to solve the problems encountered } \\
\text { in the activity design process when benefitting from technology. }\end{array}$ & A4 \\
\hline $\begin{array}{l}\text { The teacher planned the activity design process in accordance with the utilization } \\
\text { of the GeoGebra. }\end{array}$ & A5 \\
\hline $\begin{array}{l}\text { The teacher anticipated the problems that could arise at every stage of the activity } \\
\text { design process and took precautions. }\end{array}$ & A6 \\
\hline $\begin{array}{l}\text { The teacher followed the ethics of teaching profession in every step of the activity } \\
\text { design process. }\end{array}$ & A7 \\
\hline $\begin{array}{l}\text { The teacher decided to teach according to the scope of the subject when design the } \\
\text { activities. }\end{array}$ & A8 \\
\hline $\begin{array}{l}\text { The teacher planned the sequence of concepts (from general to specific and simple } \\
\text { to complex) in the activity design process. }\end{array}$ & A9 \\
\hline The teacher designed activities appropriate to the mathematics lesson plan. & A10 \\
\hline $\begin{array}{l}\text { The teacher predicted the possible misconceptions of the students and designed } \\
\text { the activities taking these misconceptions into consideration. }\end{array}$ & A11 \\
\hline $\begin{array}{l}\text { The teacher designed activities by considering how many lesson hours required } \\
\text { for completing learning outcomes of a topic. }\end{array}$ & A12 \\
\hline $\begin{array}{l}\text { The teacher appropriately transferred the subject matter that he/she will be } \\
\text { teaching into the GeoGebra software. }\end{array}$ & A13 \\
\hline $\begin{array}{l}\text { The teacher appropriately transferred the knowledge of operations into the } \\
\text { GeoGebra software. }\end{array}$ & A14 \\
\hline The teacher had information about the current issues in his/her field. & A15 \\
\hline $\begin{array}{l}\text { The teacher created the activity by combining content, pedagogy, and technology } \\
\text { knowledge. }\end{array}$ & A16 \\
\hline $\begin{array}{l}\text { The teacher was able to concretize meanings from his/her abstract mathematical } \\
\text { experiences. }\end{array}$ & A17 \\
\hline $\begin{array}{l}\text { The teacher was able to make abstraction by making meaning from his/her } \\
\text { mathematical concrete experiences. }\end{array}$ & A18 \\
\hline $\begin{array}{l}\text { The teacher designed activities that would allow students to use mathematical } \\
\text { thinking. }\end{array}$ & A19 \\
\hline $\begin{array}{l}\text { The teacher was able to adapt activities during the design process where students } \\
\text { would have trouble on learning a subject. }\end{array}$ & A20 \\
\hline $\begin{array}{l}\text { The teacher was able to create problem-solving based scenarios for teaching } \\
\text { content. }\end{array}$ & A21 \\
\hline $\begin{array}{l}\text { The teacher tried to apply the information associated with real-life in the process } \\
\text { of designing an activity. }\end{array}$ & A22 \\
\hline $\begin{array}{l}\text { The teacher was able to simultaneously re-arrange and modify an activity during } \\
\text { the design process. }\end{array}$ & A23 \\
\hline $\begin{array}{l}\text { The teacher decided goals that were appropriate for learning outcomes when } \\
\text { planning an event. }\end{array}$ & A24 \\
\hline The teacher correctly used its own unique symbols and terms of mathematics. & $\mathrm{A} 25$ \\
\hline $\begin{array}{l}\text { During the activity design process, the new information was provided by recalling } \\
\text { the old information. }\end{array}$ & A26 \\
\hline $\begin{array}{l}\text { In the activity design process, the GeoGebra software was appropriately combined } \\
\text { with teaching approaches. }\end{array}$ & A27 \\
\hline
\end{tabular}




\section{Findings}

When presenting the findings, the data collected from different data collection tools were presented together. Each teacher was treated as separate case, and the teachers' responses to the interview questions and behaviors that they exhibited were presented in details.

\section{1. Reflections from Teacher 1's Activity Design Processes}

We observed a total of 10 activity preparation processes of Teacher 1 when teaching seventh grade polygons topic that had five learning outcomes. These learning outcomes were as follows: Explains the edge and angle properties of regular polygons; Determines the internal and external angles and diagonals of the polygons and calculates the sum of the interior and exterior angles; Recognizes rectangles, parallelograms, trapezoids, and rhombuses and determines their angle properties; Forms the connections between the area properties of rhombus and trapezoid and solves related problems; Solves problems related with the field. TPACK behaviors of Teacher 1 were presented in Table 3 .

Table 3. The TPACK behaviors of Teacher 1 during the activity design processes

\begin{tabular}{|l|l|l|l|}
\hline Behaviors & $\begin{array}{l}\mathrm{f} \\
\text { (The number of } \\
\text { exhibited } \\
\text { behaviors) }\end{array}$ & Behaviors & $\begin{array}{l}\text { f } \\
\text { (The number of } \\
\text { exhibited } \\
\text { behaviors) }\end{array}$ \\
\hline A1 & 2 & A15 & 3 \\
\hline A2 & 2 & A16 & 8 \\
\hline A3 & 10 & A17 & 10 \\
\hline A4 & 0 & A18 & 0 \\
\hline A5 & 10 & A19 & 4 \\
\hline A6 & 1 & A20 & 1 \\
\hline A7 & 8 & A21 & 0 \\
\hline A8 & 10 & A22 & 0 \\
\hline A9 & 8 & A23 & 10 \\
\hline A10 & 10 & A24 & 4 \\
\hline A11 & 0 & A25 & 10 \\
\hline A12 & 1 & A26 & 2 \\
\hline A13 & 10 & A27 & 0 \\
\hline A14 & 5 & & \\
\hline
\end{tabular}

When Table 3 was examined, we recognized that the teacher mostly exhibited the following behaviors: "The teacher was able to keep up-to-date her technological knowledge" (A3), "The teacher planned the activity design process in accordance with the utilization of the GeoGebra" (A5), "The teacher decided to teach according to the scope of the subject when design the activities" (A8), "The teacher designed activities appropriate to the mathematics lesson plan" (A10), "The teacher appropriately transferred the subject matter that she will be teaching into the GeoGebra software" (A13), "The teacher was able to concretize meanings from her abstract mathematical experiences" (A17), "The teacher was able to simultaneously re-arrange and modify an activity during the design process" (A23), and "The teacher used its own unique symbols and terms of mathematics" (A25). As an example to demonstrate some of these behaviors, we provided the following exchanges between the interviewer and teacher on the "Explains the edge and angle properties of regular polygons" learning outcome:

Int: Why did you start with a triangle?

Teacher 1: This is a topic that they have prior knowledge about, so it is easy for them to understand this topic. I do not want them have trouble in the following weeks (A20).

Int: What kind of trouble?

Teacher 1: They are having trouble seeing the connection between the edge, diagonal, and angles. I present polygons starting from the ones with 3 edges, next introduce the ones with 4 
edges, and finally with 5 edges. So, I want them see the relationships among these polygons them (A8, A10).

In these exchanges, we observed the following behaviors of Teacher 1: "The teacher decided to teach according to the scope of the subject when design the activities" (A8), and "The teacher designed activities appropriate to the mathematics lesson plan" (A10), and "The teacher was able to adapt activities during the design process anticipating where students would have trouble on learning a subject" (A20), which was the least observed behavior of her. As another example, we provided an activity prepared by Teacher 1 on the GeoGebra software in Figure 1.
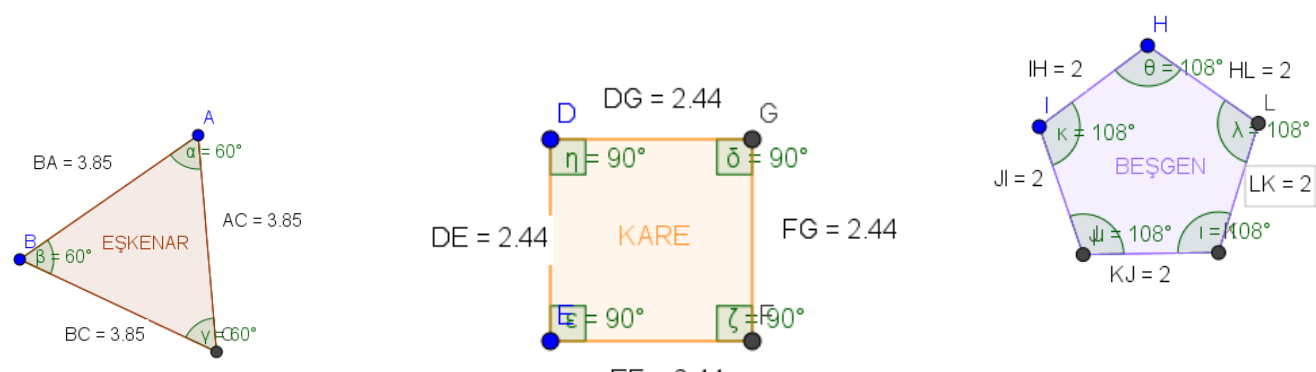

$$
E F=2.44
$$

Figure 1. An activity prepared by Teacher 1 showing the edge and angle properties of polygons.

In this example, Teacher 1 exhibited the behavior A13, "The teacher appropriately transferred the subject matter that she will be teaching into the GeoGebra software." On the other hand, Table 3 showed that Teacher 1 did not exhibit the following behaviors during the activities that she prepared: A4, A11, A18, A21, A22, and A27 (see Table 2). We provided the following activity that Teacher 1 prepared for teaching the learning outcome, "Solves problems related with the field," to illustrate this situation.
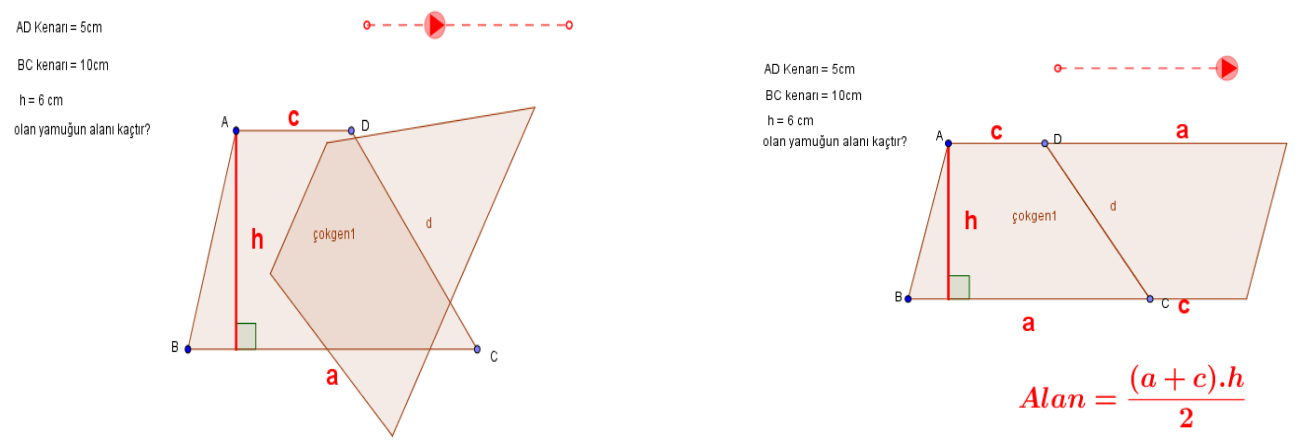

Figure 2. Example of activities related to the field.

When interviewing Teacher 1 on the above activity, she stated that the students were experiencing difficulties with this topic and accepted that she was not expecting to help students overcome these difficulties with this activity. Next, she stated that she will not prepare another activity on this topic and could not develop another method to overcome the students' difficulties. The following statement summarizes this situation:

"Generally, geometry is a topic that we have difficulty in teaching, and trapezoids are part of it. Maybe, I should have concretized trapezoids using different formats. But I do not know how to do it on the GeoGebra."

The above-mentioned behaviors that Teacher could not demonstrate showed that she had pedagogical knowledge but had difficulty in transferring this knowledge into technological platforms. 


\section{2. Reflections from Teacher 2's Activity Design Processes}

We observed a total of nine activities of Teacher 2 on five learning outcomes. We determined that Teacher 2 had deficiencies in his content, pedagogy, and technology knowledge as well as some problems in adapting pedagogy into technology. The TPACK behaviors of Teacher 2 when designing activities were presented in Table 4.

Table 4. The TPACK behaviors of teacher 2 during the activity design processes

\begin{tabular}{|l|l|l|l|}
\hline Behaviors & $\begin{array}{l}\text { f } \\
\text { (The number of } \\
\text { exhibited } \\
\text { behaviors }\end{array}$ & Behaviors & $\begin{array}{l}\text { f } \\
\text { (The number of } \\
\text { exhibited } \\
\text { behaviors })\end{array}$ \\
\hline A1 & 1 & A15 & 5 \\
\hline A2 & 2 & A16 & 0 \\
\hline A3 & 9 & A17 & 9 \\
\hline A4 & 0 & A18 & 0 \\
\hline A5 & 6 & A19 & 1 \\
\hline A6 & 0 & A20 & 2 \\
\hline A7 & 3 & A21 & 0 \\
\hline A8 & 3 & A22 & 0 \\
\hline A9 & 4 & A23 & 5 \\
\hline A10 & 6 & A24 & 0 \\
\hline A11 & 0 & A25 & 6 \\
\hline A12 & 0 & A26 & 1 \\
\hline A13 & 9 & A27 & 0 \\
\hline A14 & 6 & & \\
\hline
\end{tabular}

When Table 4 was examined, in nine activities, Teacher 2 exhibited the behaviors that were coded as "The teacher was able to keep up-to-date his technological knowledge." (A3), "The teacher appropriately transferred the subject matter that he will be teaching into the GeoGebra software." (A13), and "The teacher was able to concretize meanings from his abstract mathematical experiences." (A17) (see Table 2). Exhibiting these behaviors suggested that the teacher had the technology knowledge; however, as can be seen in the following exchanges and activity, he had deficiencies in terms of the pedagogical content knowledge.

Int: Are students having difficulty with polygons? Do they have misconceptions on this topic? Teacher 2: Generally, yes.

The exchange showed that Teacher 2 was aware of the students' misconceptions. The activity that he designed for teaching the learning outcome, "Recognizes rectangles, parallelograms, trapezoids, and rhombuses and determines their angle properties," was presented in Figure 3.

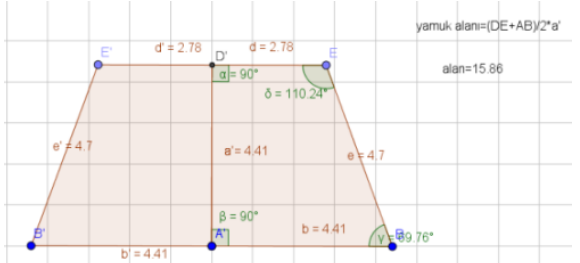

Figure 3. The activity Teacher 2 designed for showing the angle, edge, diagonal properties of a trapezoid.

In the trapezoids activity, it was evident that choosing only an isosceles trapezoid example could lead to a misconception about the shape of trapezoids, which is very common among students. When designing an activity on the learning outcome, "Solves problems related with the field," the following exchanges occurred between the interviewer and teacher: 
Int: I noticed that you showed numerical values by means of decimals. Was there any reason for doing this?

Teacher 2: No, it was a coincidence.

Int: Could using decimals in showing values cause any difficulties in the students' learning?

Teacher 2: Yes, it could.

As seen in the above exchanges, Teacher 2 did not carry out the activity in the context of pedagogy. Hence, this might have caused failure of exhibiting many behaviors in terms of TPACK.

\section{3. Reflections from Teacher 3's Activity Design Processes}

Teacher 3 designed a total of 15 activities for five learning outcomes. We presented his behaviors that occurred during the activity design processes in Table 5.

Table 5. The TPACK behaviors of Teacher 3 during the activity design processes

\begin{tabular}{|l|l|l|l|}
\hline Behaviors & $\begin{array}{l}\text { f } \\
\text { (The number of } \\
\text { exhibited } \\
\text { behaviors) }\end{array}$ & Behaviors & $\begin{array}{l}\text { (The number of } \\
\text { exhibited } \\
\text { behaviors })\end{array}$ \\
\hline A1 & 0 & A15 & 10 \\
\hline A2 & 3 & A16 & 3 \\
\hline A3 & 15 & A17 & 15 \\
\hline A4 & 1 & A18 & 2 \\
\hline A5 & 8 & A19 & 2 \\
\hline A6 & 0 & A20 & 0 \\
\hline A7 & 13 & A21 & 1 \\
\hline A8 & 8 & A22 & 1 \\
\hline A9 & 3 & A23 & 1 \\
\hline A10 & 10 & A24 & 1 \\
\hline A11 & 1 & A25 & 14 \\
\hline A12 & 1 & A26 & 3 \\
\hline A13 & 12 & A27 & 0 \\
\hline A14 & 14 & & \\
\hline
\end{tabular}

Table 5 showed that Teacher 3 mostly exhibited the following behaviors: "The teacher was able to keep up-to-date his/her technological knowledge." (A3), "The teacher was able to concretize meanings from his/her abstract mathematical experiences." (A17), "The teacher appropriately transferred the knowledge of operations into the GeoGebra software." (A14) and "The teacher correctly used its own unique symbols and terms of mathematics." (A25). To illustrate some of these behaviors, we provided four activity design processes (Figure 4) on the learning outcome, "Explains the edge and angle properties of regular polygons."

When the below activities were examined, the teacher's ability to design appropriate activities on the learning outcome and learning process suggested that he exhibited behaviors A8 and A5, respectively. Moreover, his ability to plan activities from simple to complex indicated behavior A9, activities being appropriate for the lesson program indicated behavior A10, transferring concepts and operations correctly indicated behaviors A13 and A14, being able to concretize the concepts indicated behavior A17, and using mathematical symbols and terms indicated behavior A25. 

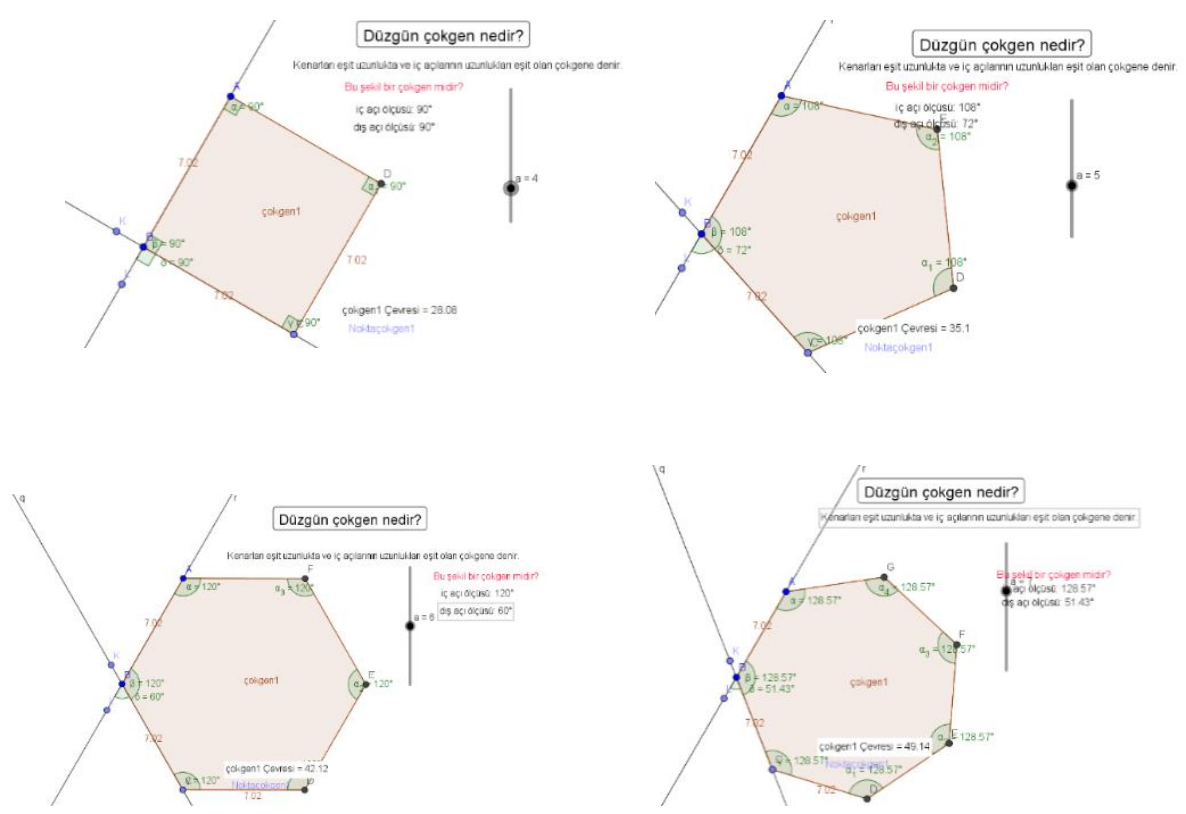

Figure 4. An activity on the edge and angle properties of regular polygons.

Besides observing teachers' activities, we also determined their TPACK behaviors from the interviews that we conducted. For instance, in below, we provided exchanges between the interviewer and Teacher 3 on the activity designed for the learning outcome, "Recognizes rectangles, parallelograms, trapezoids, and rhombuses and determines their angle properties."

Teacher 3: I have something in my head. I have to find a picture from the internet (A2).

Int: What kind of picture are you looking for?

Teacher 3: It can be something with a shape of quadrilateral. Tiles are an example of everyday life. Before starting this kind of activity, I can ask some questions about tiles and draw attention (A22).

Int: What kind of questions?

Teacher 3: A can start with a question like "Can you describe the shapes of tiles you see around?" and discuss answers in classroom (A19).

Before designing an activity on the learning outcome, "Determines the internal and external angles and diagonals of the polygons and calculates the sum of the interior and exterior angles," Teacher 3 designed a draft plan and later moved to the application process. The following exchanges occurred between the interviewer and teacher during this process:

Int: Do you always make a plan before the lecture on a subject?

Teacher 3: Yes.

Int: Can I learn the reason?

Teacher 3: By making a plan, I become more controlled. What is my purpose? (A24) I try to do something after thinking over my purpose (A10). Sometimes, I give more information that are not related with the topic.

Int: When making a plan, do you consider something?

Teacher 3: As I just mentioned, in my first year of the profession, I was giving a lot of information about the topic but over time I have changed it. I apply my plans as required in the lesson plan. I pay attention to the lesson hours required for teaching a topic (A12). 
As seen in the above exchanges, teachers' attention to the lesson plan when designing an activity indicated behavior A10, thinking over the purpose indicated behavior A24, and paying attention to the lesson hours required for teaching a topic indicated behavior A12. As a result, Teacher 3's activities suggested that he was able to combine content, pedagogy, and technology knowledge. Thus, we can conclude that he sufficiently utilized his TPACK when designing activities that were intended to be used in his classroom.

\section{Discussion and Conclusions}

There are studies (e.g., Harris, Grandgenett \& Hofer 2010; Hofer, Grandgenett, Harris \& Swan 2011) that suggest teachers' TPACK should be revealed by examinations such as interviews, prepared activities, and lesson plans, and using these types examinations would reveal more accurate results than using TPACK scales, which believed to reveal only teachers' thinking. For this reason, in this study, after spending long time on the observation form, the teachers' utilizations of the TPACK were examined in detail during the activity design process using the GeoGebra dynamic mathematics software.

In a comprehensive literature review, we recognized that it was unclear how mathematics teachers' utilizations of the TPACK will be determined and evaluated when preparing activities with dynamic software. Moreover, we recognized that most of the TPACK scales were conducted with preservice teachers,' and their utilizations of the TPACK were not examined through observation. However, in this study, each item of the observation form, which we developed, can be utilized in learning environments in which the TPACK and dynamic mathematical software used together. For example, in this study, the behavior A16 (The teacher created the activity by combining content, pedagogy, and technology knowledge) corresponds with Koehler and Mishra's (2008) statement, it is important for teachers to know knowledge structures arising from pedagogy, content, and technology to effectively integrate technology into their lessons. Similarly, the behavior A25 (The teacher correctly used its own unique symbols and terms of mathematics) is important for correctly reflecting the thinking that arises on mathematical relations, which is also pointed in NCTM (2000). In addition, the behavior A3 (The teacher was able to keep up-to-date his/her technological knowledge), which was included in the design phase of the TPACK qualification scale of Kabakç1-Yurdakul et al. (2012), emphasized the importance of keeping the technology knowledge up-to-date. In the TPACK scale that Archambault and Crippen (2009) developed they pointed out the importance of teachers' decisions on the scope of concepts and their rankings of these concepts on a specific plan. Thus, the literatures on teacher competencies support the contents of our observation form.

A teacher with TPAB can integrate content, pedagogy, and technology knowledge and at the same time can create opportunities for students to discover mathematical information. However, most of the teachers who participated in the study were found to have problems with integrating pedagogy and technology. Mudzimiri (2012) defined TPACK as a new concept which developed with experience. For every change in this style, teachers need to understand well a new development, assimilate it, and apply it effectively (Baki 2002) because as reported by Schmidt et al. (2009), teachers' content and pedagogical knowledge do not change in a technological environment, only their attitudes change. The TPACK development can only occurs in environments with technological equipment (Kokoç 2012).

As we discussed in the previous section, the GeoGebra activity design processes differed among the mathematics teachers. The teachers generally had positive opinions on the technology and reflected this positiveness on their work accordingly. In this regard, the teachers actively used the GeoGebra dynamic software at the basic level, and they tried to improve their students' mathematical thinking by the use of technology. However, they had difficulties in designing daily-life activities using the GeoGebra. Nevertheless, it is important for students to strengthen their connections with mathematics, understand the language of mathematics, and solve the problems they face in daily-life (Doruk \& Umay 2011). In addition, the teachers were often able to combine the content and technology knowledge but could not support this knowledge with pedagogical components. Integrating technology into mathematics has been an important topic that has been studied over a long period of time. However, when the literature was examined, studies (e.g., Krajcik et al. 1999) showed teachers' 
difficulties integrating technology into education, and some other studies (e.g., Tondeur et al. 2017) suggested teacher-training institutions to take an active role in ensuring the link between the content, pedagogy, and technology knowledge.

We observed that the teachers kept their GeoGebra knowledge up-to-date and took advantage of its practical aspects for to ease their students' utilizations of this software. One of the most observed teacher behavior was that they were able to concretize the abstract concepts using the GeoGebra software. This was an important behavior of the teachers because as pointed out by Hazzan and Goldenberg (1997), it is essential for teachers to enhance their students' imagination by concretizing abstract concepts. On the other hand, although the teachers stated that they want to design activities that would enhance their students' mathematical thinking, they were able to design only very limited number of activities in environments with technological possibilities. However, Dreyfus and Eisenberg (1996) emphasized the importance of mathematical reasoning for abstraction, generalization, and making meaning. Similarly, mathematical reasoning can be conceptualized as the ability to reason and understand mathematical concepts in order to arrive at a conclusion or a decision (Merriam-Webster 2014).

When Teacher 1's TPACK behaviors were examined, she had content and technology knowledge, but her PCK was not that good standing because she used the GeoGebra as a tool for carrying out activities on a visual platform without considering the students' misconceptions of the concept. The PCK is the knowledge by what teachers organize the appropriate instruction for students by combining the content and method knowledge (Shulman 1987). Teacher 1 was a level 2 (e.g., Demir 2011) teacher and her deficiencies of the TPACK level may have resulted in this insufficient PCK.

Teacher 2 had the technology knowledge but had deficiencies in the content and pedagogy knowledge. As a result of the semi-structured interviews, the teacher identified as being in level 1. His utilization of technology as a visual tool during the activity design process supported his behaviors that we identified from the observation from. According to Yilmaz (2015), when a teacher is lacking on the pedagogy and content knowledge, we cannot talk about that person's TPACK because it is important to have a close relationship between a teacher's teaching approach and the learning of the students (Trigwell \& Prosser 1999).

When the behaviors of Teacher 3, who was a level 3 teacher, were examined, we determined that he was able to design activities for his students and facilitated their learning by enhancing mathematical thinking. Moreover, he designed activities associated with daily-life and had the technology, pedagogy, and content knowledge and their components. The outcomes of Teacher 3's case and technology utilization requirements for level 3 were directly proportional. Thus, we conclude that his utilization of the TPACK during the activity design processes was sufficient enough.

\section{References}

[1] Airasian, P. W. \& Walsh, M. E. (1997). Constructivist cautions. Phi Delta Kappan, 6(78), 444449.

[2] Akyüz, D. (2016). TPACK analysis of preservice teachers under different instruction methods and class levels. Turkish Journal of Computer and Mathematics Education,7(1), 89-111.

[3] Anderson, T. (2008). Towards a theory of online learning, in Anderson, T. (Ed.) Theory and practice of online learning, 2nd ed. (pp. 45-74). AU Press.

[4] Archambault, L. \& Crippen, K. (2009). Examining TPACK among K-12 online distance educators in the United States. Contemporary Issues in Technology and Teacher Education, 9(1), 71-88.

[5] Arzarello, F., Olivero, F., Paola, D. \& Robutti, O. (2002). A cognitive analysis of dragging practises in Cabri environments. Zentralblatt für Didaktik der Mathematik, 34(3), 66-72.

[6] Baltac1, S. (2014). An investigation of the use of dynamic mathematics software in teaching the concept of locus in terms of contextual learning. Unpuplished Doctoral Thesis, Karadeniz Technical University, Institute of Educational Sciences. 
[7] Baltac1, S. \& Baki, A. (2017). The role of GeoGebra software in constructing a contextual learning environment: The case of ellipse. Ahi Evran University Journal of Kırşehir Education Faculty (JKEF), 18(1), 429-449.

[8] Baltac1, S, Yıldız, A. \& Kösa, T. (2015). The potential of GeoGebra dynamic mathematics software in teaching analytic geometry: The opinion of pre-service mathematics teachers. Turkish Journal of Computer and Mathematics Education, 6(3), 483-505.

[9] Ceylan, B., Türk, M., Yaman, F. \& Kabakçı-Yurdakul, I. (2014). Determining the changes of information and communication technology guidance teacher candidates' technological pedagogical content knowledge competency information and communication technology usage stages and levels. Journal of Theory and Practice in Education, 10(1), 171-201.

[10] Demir, S. (2011). Two inseparable facets of technology integration programs: technology and theoretical framework. EURASIA Journal of Mathematics, Science \& Technology Education, $7(2), 14$.

[11] Doruk, B. K. \& Umay, A. (2011). The effect of mathematical modeling on transferring mathematics into daily life. Hacettepe University Journal of Education, 41, 124-135.

[12] Dreyfus, T. \& Eisenberg, T. (1996). On different facets of mathematical thinking. In: R. J. Sternberg, \& T. Ben-Zeev (Eds.), The Nature of Mathematical Thinking (pp. 253-284). Hillsdale, NJ: Erlbaum

[13] Er, S. \& Sağlam-Kaya, Y. (2017) Prospective secondary mathematics teachers' views on task design at geogebra environment. Mersin University Journal of the Faculty of Education,13, 228-243.

[14] Graham, C. R., Burgoyne, N., Cantrell, P., Smith, L., St. Clair, L. \& Harris, R. (2009). TPACK development in science teaching: Measuring the TPACK confidence of inservice science teachers. TechTrends, 53(5), 70-79.

[15] Guzey, S. S. \& Roehrig, G. H. (2009). Teaching science with technology: Case studies of science teachers' development of technology, pedagogy and content knowledge. Contemporary Issues in Technology and Teacher Education, 9(1), 25-45.

[16] Gündüz, Ş. \& Odabaşı, F. (2004). The importance of instructional technologies and material development course at pre-service teacher education in information age. The Turkish Online Journal of Educational Technology-TOJET, 3(1), 43-48.

[17] Hazzan, O. \& Goldenberg, E. P. (1997). Students' understanding of the notion of function in dynamic geometry environments. International Journal of Computers for Mathematical Learning, 1, 263-291.

[18] Hofer, M., Grandgenett, N., Harris, J. \& Swan, K. (2011). Testing a TPACK-based technology integration observation instrument. Teacher Education Faculty Proceedings \& Presentations, Paper 19. Retrieved 15 May 2017 from http://digitalcommons.unomaha.edu/tedfacproc/19.

[19] Hohenwarter, M. \& Jones, K. (2007). Ways of linking geometry and algebra: The case of Geogebra. Proceedings of the British Society for Research into Learning Mathematics, 27(3), 126-131.

[20] Jang, S. J. \& Chen, K. C. (2010). From PCK to TPACK: Developing a transformative model for pre-service science teachers. Journal of Science Education and Technology, 19(6), 553-564.

[21] Kabakç1-Yurdakul, I. (2011). Examining technopedagogical knowledge competencies of preservice teachers based on ICT usage. Hacettepe University Journal of Education, 40, $397-$ 408.

[22] Kabakçı-Yurdakul, I., Odabaş1, H. F., Kılıçer, K., Çoklar, A. N., Birinci, G. \& Kurt, A. (2012) The development, validity and reliability of TPACK-deep: A technological pedagogical content knowledge scale. Computers \& Education, 58(3), 964-977. 
[23] Karataş, İ., Pişkin-Tunç, M., Demiray, E. \& Yılmaz, N. (2016) The development of pre-service teachers' technological pedagogical content knowledge in mathematics instruction. Abant İzzet Baysal University Journal of Faculty of Education, 16(2), 512-533.

[24] Koehler, M. J. \& Mishra, P. (2008). Introducing TPCK. AACTE Committee on Innovation and Technology (Ed.), The Handbook of Technological Pedagogical Content Knowledge.

[25] Kokoç, M. (2012). A Study on technological pedagogical content knowledge experiences of primary school teachers throughout blended teacher professional development. Unpuplished $\mathrm{PhD}$ Thesis, Karadeniz Technical University, Institute of Educational Sciences.

[26] Komis, V., Ergazakia, M. \& Zogzaa, V. (2007). Comparing computer-supported dynamic modeling and "paper \& pencil" concept mapping technique in students' collaborative activity. Computers \& Education, 49(4), 991-1017.

[27] Krajcik, J., Czerniak, C. \& Berger, C. (1999). Teaching children science: A project-based approach. New York: McGraw-Hill College.

[28] Kuşkaya-Mumcu, F., Haşlaman, T. \& Koçak-Usluel, Y. (2008). Indicators of effective technology integration based on technological pedagogical content knowledge model. 8 th International Educational Technology Conference, 296-299.

[29] Kutluca, T. \& Zengin, Y. (2011). Evaluation of views of students about using GeoGebra in teaching of mathematics. Dicle University Journal of Ziya Gökalp Faculty of Education, 17, 160-172.

[30] McCannon, M. \& Crews, T. B. (2000). Assessing the technology needs of elementary school teachers. Journal of Technology and Teacher Education, 8(2), 111-121.

[31] McGartland, R. D., Berg-Weger, M., Tebb, S., Lee, E. S. \& Rauch, S. (2003). Objectifying content validity: Conducting a content validity study in social work research. Social Work Research, 27(2), 94-104.

[32] Mishra, P. \& Koehler, M. (2006). Technological pedagogical content knowledge: A framework for teacher knowledge. Teachers College Record, 108 (6), 1017-1054.

[33] Morsink, P. M., Hagerman, M. S., Heintz, A., Boyer, M., Harris, R. \& Kereluik, K. (2011). Professional development to support TPACK technology integration: The Initia learning trajectories of thirteen fifth- and sixth-grade educators, Journal of Education, 191(2), 3-18.

[34] Mudzimiri, R. (2012). A study of the development of technological pedagogical content knowledge (TPACK) in pre-service secondary mathematics teachers. Doctoral Dissertation, Retrieved from ProQuest Dissertations and Theses. (Publication No. 3523442).

[35] NCTM (2000). Principles and Standards for School Mathematics. Reston, VA: National Council of Teachers of Mathematics.

[36] Niess, M. L., Van-Zee, E. H. \& Gillow-Wiles, H. (2011). Knowledge growth in teaching mathematics/science with spreadsheets: Moving PCK to TPACK through online professional development. Journal of Digital Learning in Teacher Education, 27(2), 42-52.

[37] Pamuk, S. (2012). Understanding preservice teachers' technology use through TPACK framework. Journal of Computer Assisted Learning, 28(5), 425-439.

[38] Pierson, M. E. (2001). Technology practice as a function of pedagogical expertise. Journal of Research on Computing in Education, 33(4), 413- 430.

[39] Rincon, L. F. (2009). Dynamic and interactive applications using GeoGebra software in the 612 mathematics curriculum. PhD Thesis, Kean University, ABD.

[40] Sangwin, C. (2007) A brief review of GeoGebra: Dynamic mathematics. MSOR Connections, $7(2), 36-38$. 
[41] Schmidt, D., Baran, E., Thompson, A., Mishra, P., Koehler, M. J. \& Shin, T. (2009). Technological pedagogical content knowledge (TPACK): The development and validation of an assessment instrument for preservice teachers. Paper presented at the 2009 Annual Meeting of the American Educational Research Association. April 13-17, San Diego, California.

[42] Shulman, L. S. (1986). Those who understand: Knowledge growth in teaching. Educational Researcher, 15(2), 4-14.

[43] Shulman, L. S. (1987). Knowledge and teaching: Foundations of the new reform. Harvard Educational Review, 57(1), 1-22.

[44] Tondeur, J., Roblin, N., Braak, J., Voogt, J. \& Prestridge, S. (2017). Preparing beginning teachers for technology integration in education: Ready for take-off? ISSN: 1475-5139 (Online) Journal homepage: Retrieved 15 Sep 2017 from http://www.tandfonline.com/loi/rtpe20.

[45] Trigwell, K. \& M Prosser, F. W. (1999). Reliations between teacher' aproaches to teching and students' aproaches to learning. Higer Education, 37, 57-70.

[46] Tuncer, M. \& Bahadır, F. (2016). Evaluations of prospective teachers according to their attitudes towards teaching profession and technopedagogic content knowledge competencies. International Periodical for the Languages, Literature and History of Turkish or Turkic, 11(9), 839-858.

[47] Y1lmaz, M. (2007). Instructional technology in training primary school teacher. Gazi University Journal of Gazi Educational Faculty, 27(1), 155-167.

[48] Yiğit, N., Alev, N., Yurt, Ö. \& Mazlum, E. (2017). The examination of technological and pedagogical properties in short film designs. Turkish Online Journal of Qualitative Inquiry (TOJQI), 8(1), 122-140.

[49] Zhao, Y., Pugh, K., Sheldon, S. \& Byers, J. (2002). Conditions for classroom technology innovations. Teachers College Record, 104 (3), 482-515.

\section{Authors}

Rabia Gül KIRIKÇILAR, Marmara University Institute of Educational Sciences, Doctoral student at the Department of Mathematics Education, İstanbul, TURKEY, e-mail: rabiakrkclr@gmail.com

Avni YILDIZ, Assist. Prof. Dr., Bülent Ecevit University, Ereğli Faculty of Education, the Department of Mathematics Education, Ereğli, Zonguldak, TURKEY, e-mail: yildiz.avni@gmail.com 